\title{
De hoogte van de uitkomstdrempel en legitimiteit*
}

\author{
Kristof Jacobs**
}

\section{Inleiding}

Wat is de feitelijke haalbaarheid van een uitkomstdrempel gelijk aan de helft van de opkomst bij de Tweede Kamerverkiezingen? In deze bijdrage beantwoord ik deze vraag vanuit het perspectief van het politiek gedrag. Daarnaast zal ik tevens ook reflecteren op de implicaties van een hoge uitkomstdrempel. Uit mijn analyse blijkt dat: (1) de voorgestelde drempel hoog genoeg is om representativiteit te garanderen, maar dat een alternatieve drempel, met name de drempel voorgesteld door de Staatscommissie, dat ook is; (2) de voorgestelde drempel wellicht te hoog is om een positief 'preventief effect' te hebben; en (3) internationale ervaringen erop wijzen dat een dergelijke hoge uitkomstdrempel ertoe kan leiden dat uitkomsten van een referendum niet als legitiem worden ervaren.

\section{Waarom correctief referendum?}

Om goed te kunnen inschatten of de voorgestelde hoogte van de uitkomstdrempel gepast is, is het belangrijk om het doel van de invoering van het correctief referendum eerst weer voor de geest te halen.

Het correctief referendum heeft volgens de initiatiefnemers onder meer tot doel om de inhoudelijke representatie van bepaalde groepen in de samenleving te herstellen (bijvoorbeeld lager opgeleiden en mensen met een lager inkomen). Het moet als het ware een antwoord zijn op de toenemende 'diplomademocratie'. Daarbij sluiten zij aan bij het advies van de Staatscommissie Parlementair Stelsel. Om ervoor te zorgen dat een referendum voldoende legitimiteit heeft, adviseert de Staatscommissie het gebruik van een uitkomstdrempel (Staatscommissie Parlementair Stelsel, 2018, 149).

De hoogte van die drempel is daarbij cruciaal: de drempel moet hoog genoeg zijn om voldoende representatief te zijn, maar laag genoeg om realistisch te zijn en daarmee het bovenvermelde doel te kunnen bereiken. Het is echter onduidelijk wat nu precies de correcte balans is tussen die twee tegengestelde elementen. Er is dus nood aan een ondergrens en een bovengrens.

* Dit is een herwerkte versie van een notitie voor de Eerste Kamer, Commissie Binnenlandse Zaken.

** Dr. Kristof Jacobs is universitair hoofddocent emperische politicologie op de afdeling politicologie aan de Radboud Universiteit Nijmegen. 


\section{Hoogte uitkomstdrempel: theoretische routes}

Men kan pogen de hoogte van de uitkomstdrempel vast te stellen op basis van theoretische argumentatie, maar daar zijn twee routes die je kunt nemen: de route die wordt gekozen door de Raad van State en in het amendement van de ChristenUnie (relateren aan de opkomst bij enkel Tweede Kamerverkiezingen), en de route die de Staatscommissie bewandelt (relateren aan de opkomst bij de Tweede Kamerverkiezingen en de provinciale statenverkiezingen). Echter, beide routes zijn op zich verdedigbaar, dus op basis van enkel deze overweging kom je er niet uit.

\section{Hoogte uitkomstdrempel: de empirische route}

Daarom is het belangrijk om ook gebruik te maken van internationale praktijken en onderzoek. Dit kan helpen met het bepalen van de onder- en bovengrens en daarbij de 'range' waarbinnen de uitkomstdrempel moet vallen om aan de hiervoor gestelde doelen te kunnen voldoen. Ik bespreek eerst kort de ondergrens (aan dit criterium wordt immers met gemak voldaan) en daarna, uitgebreider, de bovengrens (hieraan wordt immers niet voldaan).

\section{De ondergrens}

Beide routes (met name relateren aan Tweede Kamer dan wel relateren aan Tweede en Eerste Kamer) lijken te voldoen aan het criterium dat de drempel hoog genoeg moet zijn om representatief te zijn. Het onderzoek van Leininger en Heyne (2017), dat ook aangehaald wordt door de Staatscommissie, geeft namelijk aan dat een drempel van minimaal 25 à 30 procent ervoor zorgt dat de uitkomst een representatieve afspiegeling van de bevolking vormt. De uitkomstdrempel moet dus minstens 25 procent zijn, 30 procent als je zeker wilt zijn. In de praktijk zal de Nederlandse uitkomstdrempel zo'n 40 procent van het electoraat zijn, dat is dus ruimschoots voldoende met het oog op dit criterium.

Blijft de vraag van de bovengrens. Hier spelen in de praktijk twee elementen, zo blijkt uit onderzoek. Allereerst kan een uitkomstdrempel zorgen voor een positief preventief effect. Daarnaast heeft een uitkomstdrempel ook effect op het draagvlak voor de uitkomst - de legitimiteit.

\section{De bovengrens}

\section{- $\quad$ Preventieve werking}

Uit internationaal empirisch onderzoek blijkt dat het referendum pas een positieve werking heeft als een wet in hoofden van politici ook daadwerkelijk weggestemd kan worden in een referendum (vergelijk Leemann \& Wasserfallen, 2016). Als alle referenda resulteren in een ongeldige uitkomst omdat de uitkomstdrempel niet wordt gehaald, is dat niet het geval. Dat zorgt ervoor dat het positieve 'preventieve effect' uitblijft.

Er moet dus een reële kans zijn dat een wetsvoorstel dat te ver afligt van de meerderheid van de bevolking in een referendum wordt tegengehouden. Enkel dan is 
het zinvol voor politici om rekening te houden met deze meerderheid van de bevolking en enkel dan kan het zorgen voor meer inhoudelijke representatie. Oftewel: enkel dan kan het referendum een remedie zijn tegen de 'diplomademocratie' en is het een antwoord op de 'Ostrogorski-paradox' waar de Staatscommissie op wijst.

\section{- 2b. De bovengrens: Legitimiteit}

Maar er is nog een tweede reden waarom de uitkomstdrempel realistisch moet zijn, en die heeft te maken met het effect op de legitimiteit van de uitkomst.

Als de drempel te hoog is, is er een groot risico dat de uitkomst niet wordt gezien als legitiem. Bij een te hoge uitkomstdrempel schiet het correctief referendum ook om deze reden zijn doel voorbij. Dit gebrek aan legitimiteit komt met name voor in gevallen waar er breed gedragen tegenstand is tegen een bepaalde wet en er een relatief hoge opkomst is. Denk daarbij bijvoorbeeld aan het Nederlandse referendum over de Europese grondwet, een referendum dat ongeldig zou zijn geweest als we rekening houden met de voor het correctief referendum voorgestelde uitkomstdrempel. ${ }^{1}$

Hieronder illustreer ik aan de hand van twee cases dat dit probleem zich ook in de praktijk voordoet daar waar er een uitkomstdrempel geldt.

\section{Twee internationale cases: British Columbia en Kaaimaneilanden ${ }^{2}$}

\section{Case 1: British Columbia}

In 2005 werd in British Columbia een referendum georganiseerd over een wijziging van het kiesstelsel. 57,69 procent van de kiezers stemde voor, 42,31 procent stemde tegen, met een opkomst van 61,48 procent. In 77 van de 79 kiesarrondissementen haalde het voorstel een meerderheid. Echter, één deel van de dubbele drempel werd niet gehaald. Hoewel beduidend meer dan 60 procent van de arrondissementen voor stemde, stemde (net) geen 60 procent van de kiezers voor het voorstel.

Hoewel er dus een duidelijke meerderheid van de kiezers voor de wijziging stemde én er een hoge opkomst was, was de uitkomst niet geldig als bindende uitkomst. Dit zorgde voor zoveel controverse dat er maar liefst tweemaal een nieuw referendum over de kwestie werd gehouden (in 2009 en 2018).

\section{Case 2: Kaaimaneilanden}

In haar brief aan de Eerste Kamer in reactie op het voorlopig verslag noemt de minister de Kaaimaneilanden als voorbeeld in verband met de hoogte van de drempel (vergelijk Kamerstuk 35129, nr. D). De Kaaimaneilanden hebben nog maar één referendum gehouden dat niet samenviel met verkiezingen. Dat referendum, over een wijziging van het kiesstelsel, vond plaats in 2012.

Ongeveer 57 procent van de kiezers ging naar de stembus en een duidelijke meerderheid van net geen 65 procent stemde voor het voorstel. Echter, ondanks deze duidelijke uitslag werd ook hier de drempel niet gehaald. Bij een dergelijke opkomst had 87,4 procent van de stemmers voor het voorstel moeten stemmen. Ook hier 
zorgde dat voor grote controverse en bleef het debat op de politieke agenda (South Sound, 2013).

\section{Nederlandse case: de impact van het Oekraïne-referendum (2016) op het Wiv-referendum (2018)}

Ook in Nederland hebben we ervaring op het gebied van de legitimiteit van referendumuitkomsten. En deze ervaring levert belangrijke inzichten op. Zo blijkt uit het onderzoek van Henk van der Kolk (2018) op basis van data over het Wiv-referendum dat een groot deel van de niet-stemmers (vaak tegenstanders van de wet) thuisbleef omdat men na het Oekraïne-referendum het gevoel had dat stemmen toch geen zin had. ${ }^{3}$ Dat zien we ook in internationaal vergelijkend onderzoek: een belangrijke reden om niet te participeren is het gevoel dat het toch niet uitmaakt en men toch niet wordt gehoord (zie ook Jacquet, 2017). Bij een onrealistisch hoge uitkomstdrempel is dat bovendien een terecht gevoel: de kans dat men voor niets gaat stemmen is immers zeer groot.

Zo creëer je een situatie waar er wel degelijk een grote tegenstand is tegen een wetsvoorstel, maar deze zich niet manifesteert in een geldige uitkomst omdat tegenstanders thuisblijven. Bovendien leveren ervaringen waar de drempel niet wordt gehaald munitie op voor een demobilisatiecampagne ('het heeft toch geen zin') en krijg je referendumuitkomsten die nóg minder representatief zijn. Zo kan een wet waar een meerderheid van de bevolking tegen is, toch doorgaan net omdat de groepen die zich niet vertegenwoordigd voelen thuisblijven. En zo blijven deze groepen niet vertegenwoordigd. Ook dan schiet het correctief referendum zijn doel dus voorbij.

\section{Een uitkomstdrempel van ongeveer 40 procent in de Grondwet: geen goed idee}

Hoe groot is dit risico met een uitkomstdrempel van ongeveer 40 procent? Als je kijkt naar de landen die vergelijkbare referendumwetgeving hebben met een uitkomstdrempel en die bovendien daadwerkelijk referenda hebben gehouden, dan is een uitkomstdrempel van ongeveer 40 procent zonder meer hoog: een uitkomstdrempel van rond de 30 procent is de norm voor referenda over gewone wetten (Aguiar-Conraria \& Magalhães, 2010). De meeste referenda zouden een uitkomstdrempel van 40 procent dan ook niet halen (conform Qvortrup, 2018). De internationale ervaring suggereert dus dat een dergelijke uitkomstdrempel ervoor zorgt dat het correctief referendum zijn doel voorbijschiet.

$\mathrm{Nu}$ kan men tegenwerpen dat het moeilijk is om a priori vast te stellen of dat in Nederland ook zo zal zijn. Referenda zijn zeldzaam, uitkomstdrempels nog zeldzamer, elk politiek systeem uniek. Daardoor is het moeilijk te voorspellen hoe wetgeving in de praktijk uitpakt, zo blijkt ook uit het vergelijkend onderzoek (Bedock, 2017). Als je dan toch de drempel op ongeveer 40 procent wilt leggen, dan wil je dus flexibiliteit houden, zodat je kunt bijsturen waar nodig. 
Die flexibiliteit heb je niet als de hoogte van de drempel vastligt in de Grondwet. Natuurlijk kan de Grondwet worden gewijzigd, maar zoals de lange voorgeschiedenis van het correctief referendum al mooi illustreert: dat duurt wel heel erg lang. Tegen die tijd zijn de burgers waar het allemaal om te doen is, de lager opgeleiden en mensen met een lager inkomen, wellicht allang weer afgehaakt.

\section{Noten}

138,9 procent tegenstanders en dus ongeveer 1 procent onder de helft van de opkomst bij de Tweede Kamerverkiezingen van 2003.

2 Het gaat hier in beide gevallen om cases met een 'approval threshold', een type drempel dat dicht bij de Nederlandse uitkomstdrempel ligt, maar niet exact hetzelfde is. Dat heeft te maken met het feit dat de Nederlandse variant correctief is en het dus niet gaat om een bepaald percentage voorstemmen, maar tegenstemmen.

3 Overigens ook bij het Oekraine-referendum bleven meer tegenstanders dan voorstanders thuis. Inderdaad, we weten dat in de Nederlandse context tegenstemmers vaker de neiging hebben om niet te gaan stemmen.

\section{Literatuur}

Aguiar-Conraria, L., \& Magalhães, P.C. (2010). Referendum design, quorum rules and turnout. Public Choice, 144 (1-2): 63-81.

Bedock, C. (2017). Reforming democracy: institutional engineering in Western Europe. Oxford: Oxford University Press.

Jacquet, V. (2017). Explaining non-participation in deliberative mini-publics. European Journal of Political Research, 56: 640-659.

Kolk, H. van der (2018). Opkomst. In: K. Jacobs (red.), Het Wiv-referendum. Nationaal Referendum Onderzoek 2018. https://kennisopenbaarbestuur.nl/media/255931/wivreferendumonderzoek-2018.pdf, geraadpleegd op 27 november 2020.

Leemann, L., \& Wasserfallen, F. (2016). The democratic effect of direct democracy. American Political Science Review, 110: 750-762.

Leininger, A., \& Heyne, L. (2017). How representative are referendums? Evidence from 20 years of Swiss referendums. Electoral Studies, 48: 84-97.

Qvortrup, M. (2018). Appendix A1: Nationwide Referendums. In: M. Qvortrup (red.), Referendums around the world. Cham: Palgrave Macmillan.

Staatscommissie Parlementair Stelsel (2018). Lage drempels, hoge dijken. Amsterdam: Boom.

South Sound (2013). Top stories of 2012 Referendum fails, vote debate continues. Cayman Compass. www.caymancompass.com/2013/01/03/top-stories-of-2012-referendumfails-vote-debate-continues/, geraadpleegd op 27 november 2020. 